\title{
Oat Hay Apparent Digestibility, Rumen Ammonia Nitrogen and Bun in Goats Supplemented with Fermented Molasses-Poultry Litter
}

\author{
${ }^{1}$ J. Santos Serrato-Corona, ${ }^{2}$ Juan Isidro Sanchez Duarte, \\ ${ }^{3}$ Manuel Murillo Ortiz and ${ }^{1} E d m u n d o$ Castellanos Perez \\ ${ }^{1}$ Facultad de Agricultura y Zootecnia, Universidad Juarez del Estado de Durango, \\ Domicilio Conocido Ejido Venecia, C.P. 35000, Dgo, Mexico \\ ${ }^{2}$ Instituto Nacional de Investigacion Forestal, Agricola y Pecuaria-CELALA Blvd, \\ Jose Santos Valdez No 1200 Col, Mariano Matamoros C.P 27440, Matamoros, Coahuila, Mexico \\ ${ }^{3}$ Facultad de Medicina Veterinaria y Zootecnia-Universidad Juarez del Estado de Durango, \\ Carretera Durango-Mezquital km 11.5. Durango, Dgo, Mexico
}

\begin{abstract}
The study was conducted to determine oat hay apparent digestibility, blood urea nitrogen and ammonia nitrogen in goats supplemented with fermented molasses-poultry litter. About 20 young Alpine Frances goats with $16.6 \pm 1.8 \mathrm{~kg}$ initial body weight were used. Goats were randomly assigned to 1 of 4 treatments in a complete randomize design. The evaluated treatments were oat hay $(\mathrm{C})$; oat hay plus $150 \mathrm{~g}$ of Molasses-Poultry litter-Soybean Meal mix (MPSM); oat hay plus $150 \mathrm{~g}$ of Molasses-Poultry litter-Wheat Meddling mix (MPWM) and oat hay plus $150 \mathrm{~g}$ of Molasses-Poultry litter-Sorghum Grain mix (MPSG). Supplements and basal diet (oat hay) were individually fed. Apparent digestibility of DM, OM, NDF, ADF and $\mathrm{N}$ were determined. Blood urea nitrogen and ammonia nitrogen were also determined. Feed intake was higher ( $p=0.0001)$ in supplemented goats compared to goats in the control group. Supplemented goats consumed more DM than those in the control group ( $\mathrm{p}=0.0003)$. Dry matter retention was not affected by supplementation $(p=0.11)$. Organic dry matter tended to increase $(p=0.08)$ in supplemented goats. Supplemented goats retained more nitrogen $(p=0.0001)$ than those in the control group with values of $6.37,10.43,8.59$ and $8.00 \mathrm{~g} \mathrm{day}^{-1}$ for

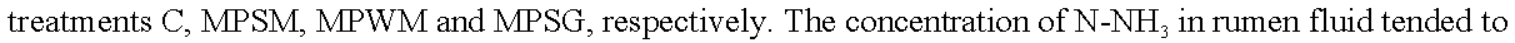
increase $(\mathrm{p}=0.08)$ as the quantity of nitrogen in the supplement increase. The results shows that supplementation with molasses-poultry litter plus soybean meal, wheat middlings or sorghum grain can increase feed intake and nitrogen retention in growing goats fed oat hay.
\end{abstract}

Key words: Goats, by-products, rumen fermentation, supplementation, quantity, supplementation

\section{INTRODUCTION}

Goat population in the Comarca Lagunera (Durango and Coahuila) Mexico is around 458271 heads. Forage quality and availability is low especially during the winter and early spring as a consequence goats nutritional status is poor. Supplementation with medium quality hay and by-products can alleviate the problem in grazing goats.

Feed intake and digestibility of low to medium quality forages can be increased by an adequate supplementation program. By-products such as poultry litter and molasses increases intake of low quality forages by ruminants. Sweetness of molasses may stimulate the intake of roughages and non desirable feeds. Processing of poultry litter such as anaerobic fermentation can improve feed intake, facilitate management and reduce pathogen organisms for ruminants, especially when mixed with carbon sources. Madrid et al. (1997) and Maity et al. (1999) reported increases on feed intake and digestibility of low quality roughages in goats supplemented with different sources of nitrogen.

An experiment was conducted to evaluate the effect of supplementation with a mix of molasses-poultry litter plus soybean meal, wheat meddling or sorghum grain on feed intake, apparent digestibility of oat hay, blood urea nitrogen and ammonia nitrogen in rumen fluid in growing goats.

\section{MATERIALS AND METHODS}

The experiment was carried out in Lucero, Durango, Mexico $\left(25^{\circ} 56^{\prime} \mathrm{N}, 103^{\circ} 26^{\prime} \mathrm{W} ; 1110 \mathrm{~m}\right.$ above sea level). Mean yearly precipitation is around $240 \mathrm{~mm}$. About

Corresponding Author: J. Santos Serrato-Corona, Facultad de Agricultura y Zootecnia, Universidad Juarez del Estado de Durango, Domicilio Conocido Ejido Venecia, C.P. 35000, Dgo, Mexico 
Table 1: Oat hay and supplements chemical composition used in the experiment

\begin{tabular}{|c|c|c|c|c|}
\hline \multirow[b]{2}{*}{ Component (\%) } & \multicolumn{4}{|c|}{ Supplement ${ }^{1}$} \\
\hline & Oat hay & MPSM & MPWM & MPSG \\
\hline $\mathrm{DM}$ & 92.00 & 69.37 & 77.33 & 74.71 \\
\hline OM & 91.80 & 86.76 & 89.50 & 89.40 \\
\hline $\mathrm{N}$ & 1.28 & 4.08 & 2.68 & 2.03 \\
\hline $\mathrm{CP}$ & 8.00 & 25.55 & 17.09 & 12.69 \\
\hline $\mathrm{NDF}$ & 66.05 & 16.22 & 24.91 & 17.12 \\
\hline $\mathrm{ADF}$ & 41.66 & 9.86 & 11.66 & 9.86 \\
\hline Ash & 8.20 & 13.24 & 10.50 & 10.60 \\
\hline
\end{tabular}

20 young Alpine Frances breed goats with $16.6 \pm 1.8 \mathrm{~kg}$ initial body weight were used. Goats were randomly allotted to 1 of 4 treatments in a complete random design with 5 goats per treatment. All goats received a basal diet of oat hay $(8.2 \% \mathrm{CP})$ at $2.2 \%$ body weight dry matter basis. Oat hay was fed following supplemental feeding each morning. Animals were individually supplemented once daily at $0600 \mathrm{~h}$, receiving $150 \mathrm{~g}$ of 1 of the 3 supplement treatments (Table 1).

Oat hay (C); oat hay plus $150 \mathrm{~g}$ of a mix $30 \%$ Molasses, 40\% Poultry litter and 30\% Soybean Meal (MPSM); oat hay plus $150 \mathrm{~g}$ of a mix $30 \%$ Molasses, $40 \%$ Poultry litter and 30\% Wheat Meddling (MPWM) and oat hay plus $150 \mathrm{~g}$ of a mix $30 \%$ Molasses, $40 \%$ Poultry litter and 30\% Sorghum Grain (MPSG).

Supplements were processed before fed, ingredients on the supplements were mixed and placed into a container on layers $20 \mathrm{~cm}$ depth, compressing the material to create an anaerobic environment and covered with a black plastic film. The ensiling period lasted 30 days. Forage and supplements sub-samples were collected every week and composited for chemical analysis. Water and salt mineral mix were available at all times.

To determine feed intake a $10 \%$ over the intake on the previous day was offered. Forage intake and refusals were recorded daily and refusals were discarded each morning prior to feeding. To estimate body weight change goats were weighed in the morning of 2 consecutive days at the beginning and the end of the experimental period. From day 29-32 fecal collection bags were fitted to the animals to assess total fecal and urine output. Every $12 \mathrm{~h}$ fecal collection bags were removed and replaced on each animal, fecal and urine output was recorded and thoroughly mixed.

Representative sub-samples $(10 \%$ of total wet weight) were collected and frozen within $1 \mathrm{~h}$ after collection at $-20^{\circ} \mathrm{C}$ for later analysis. Daily sub-samples were composited by weight (10\% wet weight) within goat and treatment an analyzed for DM, OM, NDF, ADF and $\mathrm{N}$ content. On day 35 of the experimental period goats were deprived of forage $12 \mathrm{~h}$ and 1 blood sample was collected before supplementation and every hour for $6 \mathrm{~h}$ after supplementation via jugular vein puncture. Blood samples were centrifuged at $3000 \times \mathrm{g}$ for $20 \mathrm{~min}$ at room temperature within $30 \mathrm{~min}$ after collection. Serum was harvested and frozen at $-20^{\circ} \mathrm{C}$ until latter analysis. Serum samples were analyzed for BUN spectrophotometrically using a commercial kit (Diagnostic Chemicals Limited, Oxford, Connecticut).

On day 37 of the experimental period goats were deprived of forage $12 \mathrm{~h}$ and $8 \mathrm{~mL}$ of rumen fluid were collected in 3 goats of each treatment by stomach tube connected to a vacuum pump. Rumen fluid was collected before supplement was fed $(0 \mathrm{~h})$ and every $2 \mathrm{~h}$ for $6 \mathrm{~h}$ after supplementation. Liquor was strained through 4 cheese cloth layers and a $10 \mathrm{~mL}$ aliquot was acidified with $2 \mathrm{~mL}$ of $50 \%(\mathrm{v} / \mathrm{v})$ hydrochloric acid. Samples were frozen at $-20^{\circ} \mathrm{C}$ until analysis could be conducted. Ammonia concentration was determined by the phenol-hypochlorite method of Broderick and Kang (1980). Feed intake, body weight change, dry matter digestibility and nitrogen retention were analyzed by analysis of variance for a completely randomized design (Steel and Torrie, 1980) while milk yield and blood urea nitrogen were analyzed by repeated measurements. All statistical analyses were performed by using the GLM procedure of SAS (SAS Inst., Inc., Cary, NC).

\section{RESULTS AND DISCUSSION}

Feed intake was higher $(\mathrm{p}=0.0001)$ in supplemented goats compared to goats in the control group (Table 2). Forage dry matter, $\mathrm{CP}$ and fiber contents affect voluntary intake however when $\mathrm{CP}$ is $<7 \%$ intake is diminished due to the important role of $\mathrm{N}$ on rumen bacteria growth (Fox et al., 1992). Madrid et al. (1997) and Maity et al. (1999) reported increases on feed intake and digestibility in supplemented goats fed low quality forages.

Protein supplementation often stimulate feed intake in cattle consuming low quality fiber (Lusby et al., 1982; Lusby and Horn, 1983; Krysl et al., 1989). By contrast, feed intake is not affected by protein supplementation when forage CP content is 11\% (Minson, 1982). Energy supplements based on cereal grains have shown to decrease the intake and digestibility of low quality forages (Moore et al., 1995). Supplemented goats gained more weight $(\mathrm{p}=0.02)$ than those fed only with oat hay as shown in Table 2.

Similar body weight gain have been reported in Boer goats fed grass hay and supplemented with soybean meal and wheat meddling (Moore et al., 2002). Brito found higher body weight gain in lambs fed silage of molassespoultry litter than in those fed only forage. In cattle consuming low quality forage higher weight gain has been reported with supplements based on soybean 
Table 2: Effect of supplementation with silage of molasses-poultry litter plus soybean meal, wheat meddling or sorghum grain on feed intake, body weight change and nutrient retention in growing goats fed oat hay

\begin{tabular}{|c|c|c|c|c|c|c|}
\hline \multirow[b]{2}{*}{ Items } & \multicolumn{6}{|c|}{ Treatment $^{1}$} \\
\hline & $\mathrm{C}$ & MPSM & MPWM & MPSG & $\mathrm{p}$-value & $\mathrm{EE}^{2}$ \\
\hline Feed intake $\left(\mathrm{g} \mathrm{day}^{-1}\right)$ & $598.30^{a}$ & $786.70^{b}$ & $784.00^{b}$ & $751.70^{b}$ & 0.0001 & 16.60 \\
\hline \multicolumn{7}{|l|}{ Intake $\left(\mathrm{g} \mathrm{day}^{-1}\right)$} \\
\hline $\mathrm{DM}$ & $550.40^{\mathrm{a}}$ & $689.60^{b}$ & $665.50^{b}$ & $664.60^{b}$ & 0.0003 & 18.56 \\
\hline OM & $505.30^{\mathrm{a}}$ & $627.80^{b}$ & $608.20^{b}$ & $607.40^{b}$ & 0.0003 & 17.04 \\
\hline NDF & 363.50 & 403.70 & 391.20 & 384.60 & 0.2100 & 12.26 \\
\hline $\mathrm{ADF}$ & 229.30 & 254.20 & 242.50 & 241.50 & 0.2300 & 7.73 \\
\hline $\mathrm{N}$ & $7.04^{\mathrm{a}}$ & $11.73^{\mathrm{d}}$ & $10.13^{\mathrm{c}}$ & $9.33^{b}$ & 0.0400 & 0.23 \\
\hline \multicolumn{7}{|l|}{ Excretion (g day ${ }^{-1}$ ) } \\
\hline $\mathrm{DM}$ & $145.00^{\mathrm{a}}$ & $209.50^{\mathrm{b}}$ & $242.70^{b c}$ & $169.10^{\text {ac }}$ & 0.0200 & 18.01 \\
\hline $\mathrm{OM}$ & $109.80^{\mathrm{a}}$ & $154.30^{b}$ & $182.10^{b}$ & $124.20^{\text {ba }}$ & 0.0200 & 14.20 \\
\hline NDF & $68.70^{\mathrm{a}}$ & $117.90^{b}$ & $129.60^{b}$ & $82.30^{\mathrm{a}}$ & 0.0090 & 10.30 \\
\hline $\mathrm{ADF}$ & $65.10^{\mathrm{a}}$ & $90.60^{\mathrm{ab}}$ & $105.90^{\mathrm{bc}}$ & $70.50^{\mathrm{ab}}$ & 0.0400 & 9.00 \\
\hline $\mathrm{N}$ & $0.66^{\mathrm{a}}$ & $1.29^{b}$ & $1.54^{b}$ & $1.33^{b}$ & 0.0040 & 0.10 \\
\hline \multicolumn{7}{|l|}{ Retained (g day ${ }^{-1}$ ) } \\
\hline DM & 405.40 & 480.00 & 422.70 & 495.40 & 0.1100 & 26.70 \\
\hline $\mathrm{OM}$ & 395.50 & 473.40 & 426.10 & 483.20 & 0.0800 & 23.10 \\
\hline $\mathrm{NDF}$ & 294.80 & 285.70 & 261.60 & 302.30 & 0.3900 & 16.70 \\
\hline $\mathrm{ADF}$ & 164.10 & 163.60 & 136.60 & 171.00 & 0.2500 & 11.80 \\
\hline $\mathrm{N}$ & $6.37^{\mathrm{a}}$ & $10.43^{\mathrm{c}}$ & $8.59^{b}$ & $8.00^{b}$ & 0.0001 & 0.27 \\
\hline \multicolumn{7}{|l|}{ Retention (\%) feed intake } \\
\hline $\mathrm{DM}$ & 67.80 & 60.90 & 54.00 & 65.80 & 0.0900 & 3.50 \\
\hline $\mathrm{OM}$ & 66.10 & 60.10 & 54.40 & 64.20 & 0.2400 & 3.00 \\
\hline NDF & $49.30^{\mathrm{a}}$ & $36.20^{b}$ & $33.40^{b c}$ & $40.20^{\mathrm{b}}$ & 0.0500 & 2.10 \\
\hline $\mathrm{ADF}$ & $27.40^{\mathrm{a}}$ & $20.70^{b}$ & $17.40^{b}$ & $22.70^{\mathrm{abc}}$ & 0.0100 & 1.60 \\
\hline $\mathrm{N}$ & $1.06^{\mathrm{a}}$ & $1.32^{b}$ & $1.09^{\mathrm{a}}$ & $1.06^{\mathrm{a}}$ & 0.0004 & 0.10 \\
\hline Body weight change $\left(\mathrm{g} \mathrm{day}^{-1}\right)$ & $6.40^{\mathrm{a}}$ & $75.00^{b}$ & $65.00^{b}$ & $39.00^{\mathrm{ab}}$ & 0.0004 & 0.02 \\
\hline
\end{tabular}

meal than with supplements based on wheat meddling or corn grain (Grigsby et al., 1992; Sr Galloway et al., 1993). Probably due to the higher protein quality, essential amino acids and 35\% bypass protein of soybean meal (NRC, 1996). Dry matter disappearance was similar between treatments $(p=0.11)$.

Effectiveness of protein supplementation in ruminants consuming low digestibility, low protein roughages may be achieved when nitrogen readily degradable to ammonia is fed to satisfy nitrogen rumen microbes requirements. Digestibility of $\mathrm{NDF}$ and $\mathrm{ADF}$ were similar $(\mathrm{p}=0.39$ and $p=0.25$, respectively) between treatments. Nitrogen retention was higher in supplemented goat $(\mathrm{p}=0.0001)$ compared to no supplemented goats. Goats supplemented with MPSM retained $10.43 \mathrm{~g}_{\text {day }}{ }^{-1}$ while those receiving MPWM and MPSG retained 8.59 and $8.0 \mathrm{~g} \mathrm{day}^{-1}$, respectively.

Nitrogen retention increased as the $\mathrm{N}$ concentration augmented in the supplement. Avitia and Serrato found a similar trend in goats supplemented with protein and fed ammoniated corn stover. Richards et al. (2006) reported an increase in nitrogen retention in cattle supplemented with soybean meal, wheat meddling and molasses $\left(16 \mathrm{~g} \mathrm{day}^{-1}\right)$ compared to those cows consuming only brome hay (7.3 $\mathrm{g} \mathrm{day}^{-1}$ ). The results implied that soybean meal

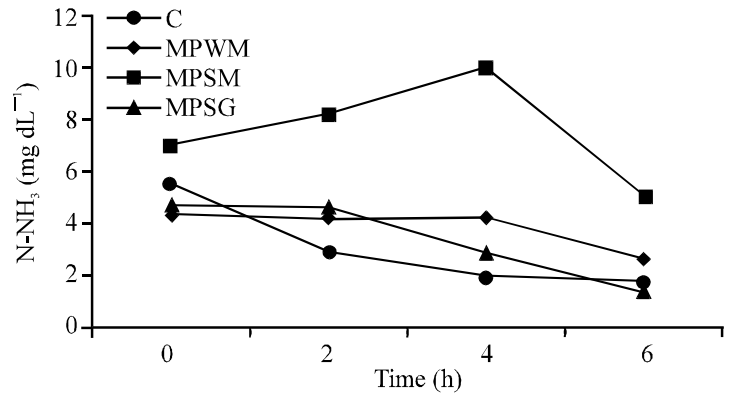

Fig. 1: Nitrogen ammonia concentration $\left(\mathrm{N}-\mathrm{NH}_{3}\right)$ in rumen fluid of growing goats fed oat hay and supplemented with molasses-poultry litter silage added with soybean meal, wheat meddling or sorghum grain $(\mathrm{p}=0.08 ; \mathrm{EE}=7.89)$

protein supplied amino acids, peptides or carbon chains for ruminal microbial population. Stern et al. (1994) pointed out that supplementation with soybean meal increase the uptake of amino acids, peptides or both by ruminal microbes. Supplemented goats showed a tendency to increase $(p=0.08)$ ammonia nitrogen in rumen fluid as nitrogen augmented in the supplement (Fig. 1). Goats receiving the MPSM showed higher $\mathrm{N}-\mathrm{NH}_{3}$ concentration (7.4 mg dL $\mathrm{m}^{-1}$ ) than the goats in the control group (2.9 $\mathrm{mg} \mathrm{dL} \mathrm{d}^{-1}$ ) with intermediate values 


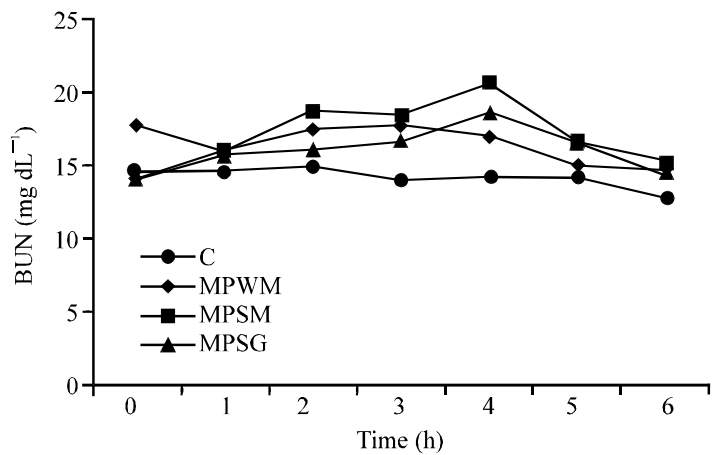

Fig. 2: Blood urea nitrogen $\left(\mathrm{mg} \mathrm{dL}^{-1}\right)$ in growing goats fed oat hay and supplemented with molassespoultry litter silage added with soybean meal, wheat meddling or sorghum grain $(\mathrm{p}=0.30$; $\mathrm{EE}=1.11)$

for the treatments MPWM (3.7 $\mathrm{mg} \mathrm{dL}^{-1}$ ) and MPSG (3.3 $\mathrm{mg} \mathrm{dL}^{-1}$ ). Similar $\mathrm{N}-\mathrm{NH}_{3}$ concentration $\left(6.52 \mathrm{mg} \mathrm{dL}^{-1}\right.$ ) was reported by Moore et al. (2002) in goats supplemented with soybean meal. Satter and Slyter (1974) and Soto-Navarro et al. (2004) indicate that $\mathrm{N}-\mathrm{NH}_{3}$ concentration is related to protein content in the supplement consumed. In steers supplemented with soybean meal the $\mathrm{N}-\mathrm{NH}_{3}$ plateau between 3 and $4 \mathrm{~h}$ after feeding (Richards et al., 2006).

Hennessey (1996) suggested a readily fermentable source of nitrogen for ammonia production to ensure adequate ruminal microbial fermentation. Nitrogen supplementation based on nonprotein nitrogen to cattle grazing dormant forages was suggested to be effective by Petersen (1987) only when ruminal ammonia concentration in ruminal fluid is $<2.0 \mathrm{mg} \mathrm{dL}^{-1}$.

Results suggest that adding a true protein source favoured nitrogen availability for rumen microbes. Blood urea nitrogen concentration was not different $(\mathrm{p}=0.3)$ between treatments with values of 17.6, 16.0, 14.2 and $16.1 \mathrm{mg} \mathrm{dL}^{-1}$ for treatments C, MPWM, MPSB and MPSG, respectively (Fig. 2).

The higher blood urea nitrogen concentration was observed between 2 and $4 \mathrm{~h}$ after supplementation. Lapierre and Lobely pointed out that protein sources resistant to rumen microbes fermentation provide the largest amount of nitrogen absorbed as amino acids, rendering a low synthesis and elimination of urea. By contrast soluble protein sources may favor $\mathrm{N}-\mathrm{NH}_{3}$ escape throughout the rumen epithelium, increasing blood urea nitrogen concentration. Serrato and Avitia reported similar concentration of blood urea nitrogen $\left(17.6 \mathrm{mg} \mathrm{dL}^{-1}\right)$ in goats fed ammoniated corn stover and supplemented with a supplement based on soybean meal, corn gluten and wheat meddling.
Dietary protein content may affect blood urea nitrogen in goats. Blood urea nitrogen concentration in this trial are in the normal physiological range reported by Morros and Dukes whom report a normal physiological range in goats from $6-28 \mathrm{mg} \mathrm{dL}^{-1}$.

\section{CONCLUSION}

The results of the current indicate that supplementation with silage of molasses-poultry litter plus soybean meal, wheat middling or sorghum grain can increase nitrogen retention in growing goats fed oat hay. Supplementation with fermented poultry litter-molasses plus soybean meal supply the ammonia nitrogen required for rumen microbesfermentation.

\section{REFERENCES}

Broderick, G.A. and J.H. Kang, 1980. Automated simultaneous determination of ammonia and total amino acids in ruminal fluid and in vitro media. J. Dairy Sci., 63: 64-75.

Fox, D.G., C.J. Sniffen, J.D. O'Connor, J.B. Russell and P.J. van Soest, 1992. A net carbohydrate and protein system for evaluating cattle diets: III. Cattle requirements and diet adequacy. J. Anim. Sci., 70: 3578-3596.

Grigsby, K.N., M.S. Kerley, J.A. Peterson and J.C. Weigel, 1992. Site and extent of nutrient digestion by steers fed a low-quality bromegrass hay diet with incremental levels of soybean hull substitution. J. Anim. Sci., 70: 1941-1949.

Hennessey, D.W., 1996. Appropriate supplementation strategies for enhancing production of grazing cattle in different environments. Proceedings of the Grazing Livestock Nutrition Conference, July 18-19, Custer, South Dakota, pp: 1-1.

Krys1, L.J., M.E. Branine, A.U. Cheema, M.A. Funk and M.L. Galyean, 1989. Influence of soybean meal and sorghum grain supplementation on intake, digesta Kinetics, ruminal fermentation, site and extent of digestion and microbial protein synthesis in beef steers grazing blue grama rangeland. J. Anim. Sci., 67: 3040-3051.

Lusby, K.S. and G.W. Horn, 1983. Energy vs protein supplementation of steers grazing native range in late summer and early fall. Oklahoma Agricultural Experiment Station, MP-114.

Lusby, K.S., G.W. Horn and M.J. Dvorak, 1982. Energy vs protein supplementation of steers grazing native range in late summer and early fall. Oklahoma Agricultural Experiment Station, MP-112, pp: 36-39. 
Madrid, J., F. Hernandez, M.A. Pulgar and J.M. Cid, 1997. Urea and citrus by-product supplementation of strawbased diets for goats: Effect on barley straw digestibility. Small Ruminant Res., 24: 149-155.

Maity, S.B., A.K. Mishra and V.S. Upadhyay, 1999. Effect of wheat bran supplementation on the utilization of mixed straws in goats. Indian J. Anim. Nutr., 16: 86-88.

Minson, D.J., 1982. Effects of Chemical and Physical Composition of Herbaje Eaten Upon Intake. In: Nutritional Limits of Animal Production from Pasture, Hacker, J.B. (Ed.). Common Wealth Agriculture Bureaux, Slough, UK., pp: 167-182.

Moore, J.A., M.H. Poore and J.M. Luginbuhl, 2002. By-product feeds for meat goats: Effects on digestibility, ruminal environment and carcass characteristics. J. Anim. Sci., 80: 1752-1758.

Moore, J.E., J.G.P. Bowman and W.E. Kunkle, 1995. Effects of dry and liquid supplements on forage utilization by cattle. Proceedings of the American Feed Industry Association Liquid Feed Symposium, Sept. 13-15, Arlington, VA. USA., pp: 81-91.

NRC. (National Research Council), 1996. Nutrient Requirements of Beef Cattle. 7th Edn., National Academy Press, Washington, DC., USA.

Petersen, M.K., 1987. Nitrogen supplementation of grazing livestock. Proceedings of the Grazing Livestock Nutrition Conference (GLNC'87), Jackson, Wyoming, pp: 115-115.
Richards, C.J., R.B. Pugh and J.C. Waller, 2006. Influence of soybean hull supplementation on rumen fermentation and digestibility in steers consuming freshly clipped endophyte-infected tall fescue. J. Anim. Sci., 84: 678-685.

Satter, L.D. and L.L. Slyter, 1974. Effect of ammonia concentration on rumen microbial protein production in vitro. Br. J. Nutr., 32: 199-208.

Soto-Navarro, S.A., M.H. Knight, G.P. Lardy, M.L. Bauer and J.S. Caton, 2004. Effect of fiber-based creep feed on intake, digestion, ruminal fermentation and microbial efficiency in nursing calves. J. Anim. Sci., 82: 3560-3566.

Sr Galloway, D.L., A.L. Goetsch, L.A. Jr Forster, A.R. Patil, W. Sun and Z.B. Johnson, 1993. Feed intake and digestibility by cattle consuming bermudagrass or orchardgrass hay supplemented with soybean hulls and (or) corn. J. Anim. Sci., 71: 3087-3095.

Steel, R.G.D. and J.H. Torrie, 1980. Principles and Procedures of Statistics a Biometrical Approach. 2nd Edn., McGraw-Hill Inc., New York, pp: 137.

Stern, M.D., G.A. Varga, J.H. Clark, J.L. Firkins, T.J. Huber and D.L. Palmquist, 1994. Evaluation of chemical and physical properties of feeds that affect protein metabolism in the rumen. J. Dairy Sci., 77: $2762-2786$. 